\title{
Gentisic Acid As a Pathogen-Inducible Signal, Additional to Salicylic Acid for Activation of Plant Defenses in Tomato
}

\author{
José María Bellés, ${ }^{1}$ Rafael Garro, ${ }^{1}$ Joaquín Fayos, ${ }^{1}$ Pilar Navarro, ${ }^{1}$ Jaime Primo, ${ }^{2}$ and \\ Vicente Conejero ${ }^{1}$ \\ ${ }^{1}$ Instituto de Biología Molecular y Celular de Plantas, and ${ }^{2}$ Instituto de Tecnlogía Química, Universidad \\ Politécnica de Valencia-Consejo Superior de Investigaciones Científicas, Camino de Vera s/n, 46022 \\ Valencia, Spain \\ Accepted 1 December 1998.
}

\begin{abstract}
Citrus exocortis viroid (CEVd) and tomato mosaic virus (ToMV), which produce a systemic non-necrotizing infection in tomato (Lycopersicon esculentum cv. Rutgers), strongly induced the accumulation of a phenolic compound that we have characterized as 2,5-dihydroxybenzoic acid (gentisic acid, GA) by nuclear magnetic resonance, following purification by high-performance liquid chromatography. Levels of free and total GA increased more than 150-fold in response to CEVd and ToMV infections. Unlike these non-necrotizing infections, the necrotizing reaction elicited by Pseudomonas syringae pv. syringae in this host did not produce any accumulation of GA. It is also shown that, in healthy leaf tissues, benzoic acid (BA) and salicylic acid (SA) were rapidly converted to GA, SA being the immediate precursor of GA, according to radiolabeling studies. Interestingly, exogenous GA elicited accumulation of the previously described CEVd-induced antifungal pathogenesis-related (PR) proteins P23, P32, and P34. These proteins were not induced by exogenous SA, which is able to elicit other CEVd-induced PR proteins in tomato. These results suggest that $\mathrm{GA}$ acts as a pathogeninduced signal, additional to $\mathrm{SA}$, for activation of plant defense genes in tomato.
\end{abstract}

Additional keywords: antifungal proteins, phenolics.

The sessile condition of plants continuously exposes them to a great diversity of potential pathogens. To cope with this permanent threat, plants have developed very efficient defensive mechanisms and, as a result, disease is the exception rather than the norm. These mechanisms consist of physical and chemical barriers (passive, preformed defenses) as well as a system of active defense reactions that are induced upon elicitation by pathogens, conferring to plants what is termed acquired resistance. This defensive response may be induced specifically, as in a gene-for-gene type of interaction, which is normally accompanied by cell death, resulting in an incom-

Corresponding author: Vicente Conejero; Telephone: 34-96-387 7850; Fax: 34-96-387 7859; E-mail: vconejer@ibmcp.upv.es

José María Bellés and Rafael Garro contributed equally to this work. patible, necrotizing interaction or hypersensitive response. In this case, the infection is restricted to small areas immediately surrounding the initially infected cells. This local reaction, in its turn, signals the activation of defensive reactions in uninfected parts of the plant that become more resistant (systemic acquired resistance, SAR; Ryals et al. 1996; Baker et al. 1997; Sticher et al. 1997; Yang et al. 1997). The defensive response can also be triggered in compatible, non-necrotizing interactions by a range of biotic and abiotic elicitors in the absence of gene-for-gene resistance in which disease develops (Conejero et al. 1990; Dixon et al. 1994; Bent 1996). This multicomponent defense response includes activation of pathways leading to biosynthesis of chemical weapons as phytoalexins and a number of other unknown antimicrobial metabolites and structural defensive barriers such as lignin and hydroxyproline-rich cell wall proteins. Also, the coordinated synthesis of an array of pathogenesis-related (PR) proteins (Ward et al. 1991; Uknes et al. 1992, 1993; Kombrink and Somssich 1995) is activated. Although the signaling of this complex defense system is far from being understood, it is generally admitted that salicylic acid (SA) has a central role in mediating SAR (Ryals et al. 1996, 1997; Cao et al. 1997). This idea is based on a large body of evidence: (i) the correlation between enhanced levels of SA and the establishment of SAR in a number of plant-pathogen encounters (Malamy et al. 1990; Métraux et al. 1990; Rasmussen et al. 1991; Malamy et al. 1992; Silverman et al. 1993; Uknes et al. 1993; Dempsey et al. 1997; Shirasu et al. 1997); (ii) exogenous application of SA resulting in the establishment of SAR, i.e., an enhanced, nonspecific resistance to subsequent infections and the normally associated accumulation of PR proteins in the treated plants (Ward et al. 1991; Malamy et al. 1996); and (iii) work with transgenic tobacco and Arabidopsis thaliana plants expressing the bacterial nah $\mathrm{G}$ gene encoding salicylate hydroxylase, an enzyme that catalyzes the conversion of SA to catechol, provided evidence linking SAR to SA accumulation (Gaffney et al. 1993). These plants cannot accumulate SA and are unable to build up an SAR response upon attack by viral, fungal, or bacterial pathogens (Delaney et al. 1994). More recently, evidence has been reported in favor of the existence of other transduction pathways leading to the induction of PR genes in an SA-independent manner (Malamy et al. 1996; 
Penninckx et al. 1996; Durner et al. 1997; Vidal et al. 1998; Hunt et al. 1997; Vallélian-Bindschedler et al. 1998; Zhang and Klessig 1998).

With the aim of finding new molecules possibly involved in SAR signaling, we directed our attention to plant phenolics, a class of compounds that have been associated with the defense of plants against pathogens (Maher et al. 1994), as components of both preformed and inducible defenses, and or as intermediary signals, as in the case of SA (Métraux and Raskin 1993). Here is described the finding that a phenolic compound, different from SA, dramatically accumulates upon the non-necrotizing infections produced by citrus exocortis viroid (CEVd) and tomato mosaic virus (ToMV) in Rutgers tomato. We have characterized this compound as 2,5-dihydroxybenzoic acid (gentisic acid, GA) and obtained evidence that GA induces the accumulation of a subset of PR proteins not induced by SA in tomato. These results suggest that, in order to broaden the spectrum of their defense possibilities, plants have evolved signal molecules complementary to SA.

\section{RESULTS AND DISCUSSION}

\section{A phenolic compound, intensively enhanced} upon CEVd infection, is characterized as GA.

High-performance liquid chromatography (HPLC) elution profile of total phenolics from leaf extracts of CEVd-infected tomato demonstrated the presence of two major peaks in chromatograms that were barely negligible in extracts from control plants (Fig. 1). One of them corresponds to SA, as assessed by its coelution with standard SA under different chromatographic conditions and by comparison of its retention time with that previously reported (Yalpani et al. 1993a). The ${ }^{1} \mathrm{HNMR}$ (proton nuclear magnetic resonance) spectrum of the purified unknown compound showed clearly the peak pattern corresponding to a 1, 2, 5 trisubstituted aromatic system. The mass spectrum gives a molecular peak at $154 \mathrm{~m} / \mathrm{z}$ compatible with the structure of GA. The comparison (Fig. 2) with the ${ }^{1}$ HNMR spectrum of a sample of standard GA showed an absolute identity, thus confirming unambiguously the structure of the isolated compound.

Figure 3A shows the dramatic accumulation of free GA produced by CEVd infection in tomato leaves. Twenty-four hours after the appearance of symptoms, the level of GA increased about 10 -fold, compared with healthy leaves, reaching a maximum level of 180-fold above basal levels 4 days later. Thereafter, GA remained constant. To test whether GA was also in a bound form, as occurred with SA (Enyedi et al. 1992; Malamy et al. 1992), we made acid hydrolysis of tomato extracts. This acidic hydrolysis liberated a high additional amount of GA. It was found that the great majority (approximately 85\%) of GA is in a conjugated form, as is the case with SA in TMV-infected tobacco (Enyedi and Raskin 1993; Lee and Raskin 1998). The bound GA was also totally released when we made an enzymatic hydrolysis of tomato extracts with $\beta$-glucosidase according to the protocol of Enyedi et al. (1992), thus indicating that the conjugated form is, most likely, a $\beta$ - $O$-D-glycosyl GA, as happened with SA in tobacco, in which SA was also converted into $\beta$-D-glucosyl SA (Enyedi et al. 1992; Malamy et al. 1992). The evolution of total GA was similar to that followed by free GA (Fig. 3B). Four days after the appearance of symptoms, total GA in- creased about 160-fold above the basal levels (Fig. 3B). To test whether the accumulation of GA was produced in other tomato-pathogen interactions we studied (i) a compatible, non-necrotizing systemic infection (ToMV), as in the case of CEVd infection, and (ii) an incompatible, necrotizing infection (Pseudomonas syringae pv. syringae), which produces a hypersensitive reaction that restricts the pathogen to small areas surrounding the infection sites. Figure $4 \mathrm{~A}$ and $\mathrm{B}$ show the free and total GA accumulation, respectively, during 7 days after the appearance of symptoms in ToMV-infected tomato leaves. As can be observed, the maximum values of GA were similar to those of free and total GA in CEVd-infected tomato leaves (Fig. 3A and B). However, infiltration of Rutgers tomato leaves with $P$. syringae pv. syringae, which produced hypersensitive response lesions at the site of bacterial inoculation commencing at $24 \mathrm{~h}$ post inoculation, did not induce any increment in the levels of free and total GA (Fig. 5A and B). This is consistent with the results obtained in the incompatible interaction produced by TMV in tobacco Xanthi-nc, which was not accompanied by GA accumulation (Yalpani et al. 1993a). It had been shown (Chadha and Brown 1974) that labeled benzoic acid (BA) was converted to both bound SA and GA in tomato plants and that SA converts to GA in some species (Ibrahim and Towers 1959; Schulz et al. 1993). In to-

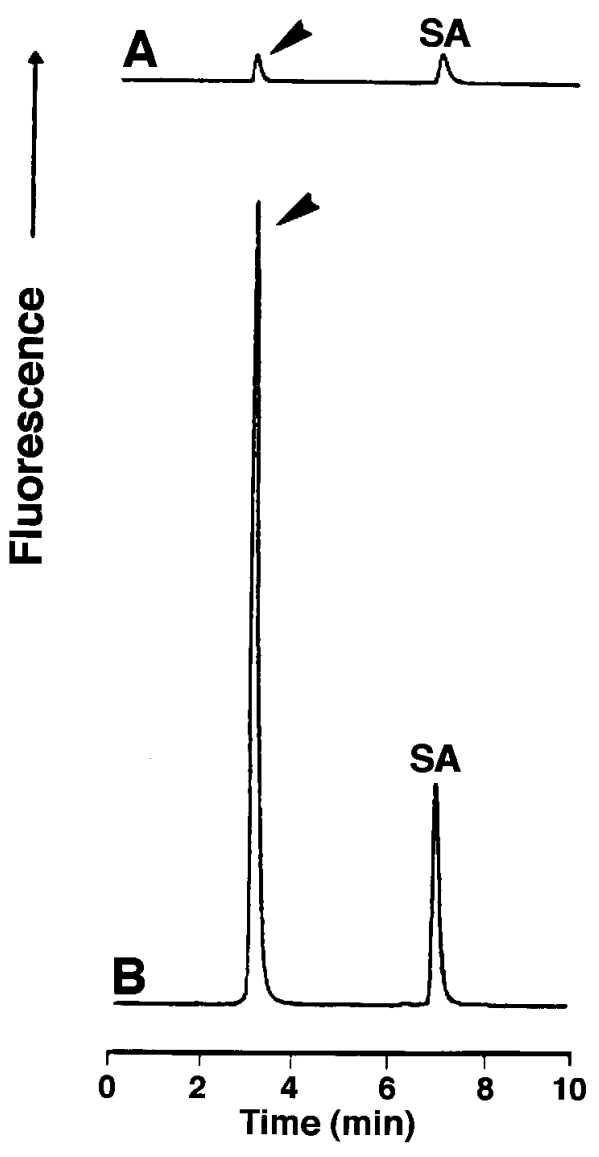

Fig. 1. High-performance liquid chromatography chromatograms from leaf extracts of (A) control and (B) citrus exocortis viroid (CEVd)infected Rutgers tomato plants. Fluorescence at an excitation wavelength of $315 \mathrm{~nm}$ and an emission wavelength of $405 \mathrm{~nm}$. SA: salicylic acid. 
bacco, it had been demonstrated that SA is synthesized from trans-cinnamic acid via BA (Yalpani et al. 1993a). Recently, the enzyme that converts BA to SA in tobacco has been partially purified and characterized (Leon et al. 1995). Its activity was strongly induced $4 \mathrm{~h}$ after infiltration of leaf disks with BA (León et al. 1993). However, there were no data on the presence of any activity in tobacco that converts SA to GA.

The preceding and our presently described results were consistent with the presence in tomato and the lack in tobacco tissues of a metabolic system with the capability not only to convert SA to GA but also to allow GA accumulation. To substantiate this idea, we studied GA accumulation in uninfected tomato plants sprayed with $10 \mathrm{mM}$ solutions of SA or BA. Forty-eight hours after tomato plants were sprayed with $10 \mathrm{mM} \mathrm{SA}$, levels of GA increased from 2.5 to $20.6 \mu \mathrm{g}$ per $\mathrm{g}$ of fresh weight. Thereafter, GA remained constant (Fig. 6A). As early as $2 \mathrm{~h}$ after the treatment, a significant increase of GA could already be observed. Again, acid hydrolysis of leaf extracts released a great amount of GA, which indicated that GA is rapidly converted to its conjugated form. The time course of accumulation of total GA after SA treatment is similar to that of the free form (Fig. $6 \mathrm{~B})$. The maximum increase of total GA (40-fold with respect to the control plants) was reached $48 \mathrm{~h}$ after treatment. Interestingly, at this time, GA was not significantly accu- mulated in tobacco tissues sprayed with $10 \mathrm{mM}$ concentrations of SA (Fig. 7A). Figure 8A and B show the levels of free and total GA in tomato leaves after tomato plants were sprayed with $10 \mathrm{mM} \mathrm{BA}$. Although at a lower rate than in SA-sprayed leaves, BA was converted to GA by tomato leaves. The levels of free and total GA were about 5 times those of the control plants within 3 days after BA treatment. The maximum values of free and total GA reached in BAtreated leaves were 1 and $6.4 \mu \mathrm{g}$ per $\mathrm{g}$ of fresh weight, respectively. Contrary to what happened in tobacco, in which a rapid accumulation of SA occurred after feeding disks with BA (Yalpani et al. 1993a; León et al. 1993) or spraying leaves with BA (Fig. 7B), no significant increments in SA was observed in tomato leaves after BA treatment (Fig. 7B). The results obtained with exogenous $\mathrm{SA}$ and BA suggest that, in healthy tomato, SA, which is not accumulated, would rapidly be 5-hydroxylated to form GA by an enzymatic activity that would be essentially absent in tobacco. This is consistent with the presently described accumulation of GA induced by CEVd and ToMV infections in tomato and with the absence of GA accumulation in TMV-infected tobacco (Yalpani et al. 1993a). In the case of $P$. syringae pv. syringae-infected tomato leaves, the enhancing of SA and lack of accumulation of GA observed would be explained by assuming that in the incompatible reaction induced by the

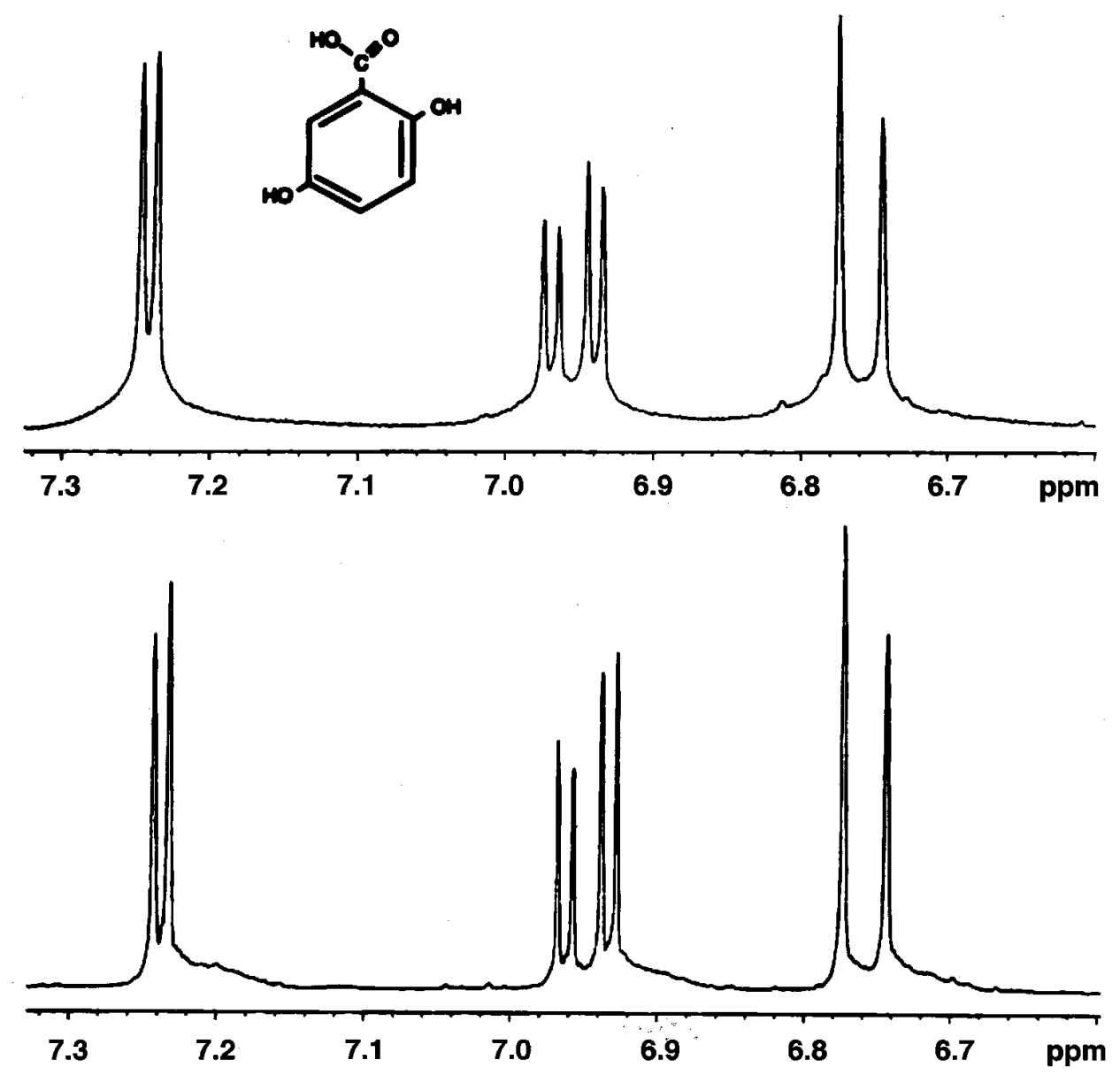

Fig. 2. ${ }^{1} \mathrm{HNMR}$ (proton nuclear magnetice resonance) of the aromatic protons of the isolated compound (top) and the authentic sample of 2,5dihydroxibenzoic acid (gentisic acid) (bottom). 
pathogen the conversion of SA into GA is somehow interfered with. To know whether SA is a direct biosynthetic precursor of GA in tomato, detached leaves were fed $\left[7-{ }^{14} \mathrm{C}\right] \mathrm{SA}$ as described in Materials and Methods. In Figure 9A and B, it is shown that, 1 and $6 \mathrm{~h}$ after the treatment, radioactivity was found accumulated 25 and $75 \%$, respectively, in a compound that coeluted with the authentic GA. This demonstrated that SA is the biosynthetic precursor of GA, as has been proposed by Meuwly et al. (1995) for cucumber.

\section{GA as intermediary signal for defense reactions.}

Although the widespread occurrence of GA is known (Griffiths 1959) and its in vitro antifungal activity has been demonstrated (Lattanzio et al. 1994), GA, to the best of our knowledge, has never been reported as a component of the inducible response of plants to pathogens, either as a mediator or as an induced antimicrobial defense. To test the possible role of the induced GA as an elicitor of plant defenses in tomato, we studied the induction of PR proteins upon treatment with exogenous GA. Since our attempts with common spraying were ineffective, as had been previously found by Van Kan et al. (1995), tomato leaves were fed $1 \mathrm{mM}$ GA or SA for
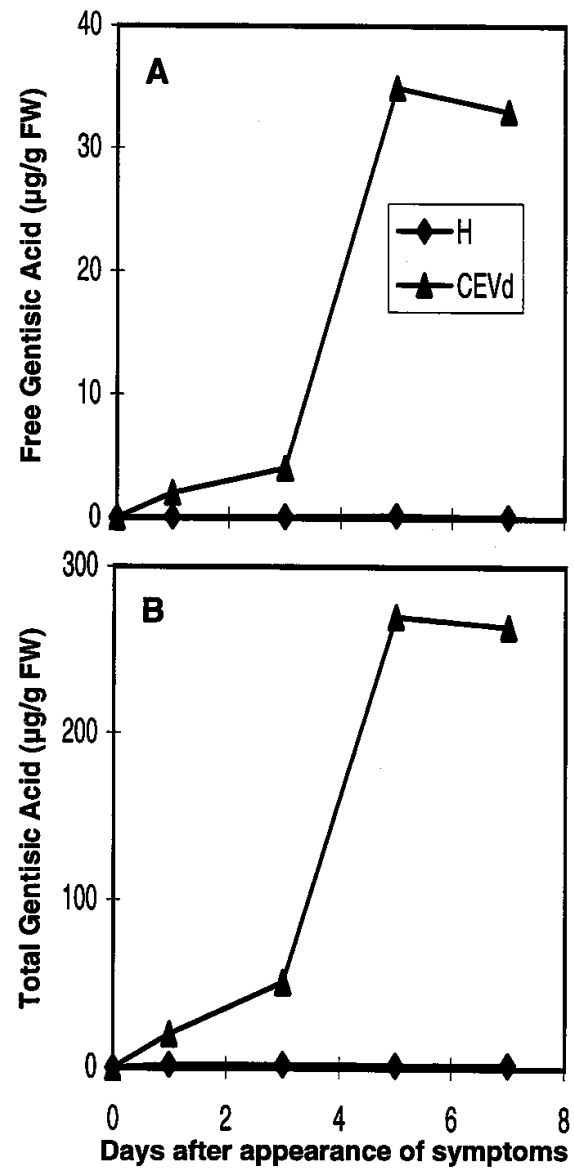

Fig. 3. Effect of citrus exocortis viroid (CEVd) infection on levels of (A) free and (B) total gentisic acid in Rutgers tomato leaves. Tomato plants were inoculated with CEVd 10 days after sowing at cotyledon stage. Symptoms appeared 10 days later. Values are the mean of two replicates differing by less than $10 \%$. The experiment was conducted three times with similar results. $\mathrm{H}$, healthy control plants. CEVd, citrus exocortis viroid-infected plants. FW, fresh weight.
$72 \mathrm{~h}$ through the cut petiole. Figure 10 shows that GA markedly induced the antifungal PR proteins P23, P32, and P34, a subset of the PR proteins that had been found to be induced by CEVd infection in Rutgers tomato (Granell et al. 1987; García-Breijo et al. 1990; Rodrigo et al. 1993). Figure 10 also shows that SA, which strongly induced the known PR-1, did not induce any of those proteins. It is pertinent to note that the endogenous level of GA, after the leaves were fed through the cut petiole with SA, was about 20 -fold lower than the endogenous level of GA reached after feeding the leaves with this latter compound. This would explain that, although SA was converted to GA, the amount of GA accumulated in the leaves was below the threshold necessary to induce the proteins. However, in Rutgers tomato, SA was able to induce other PR proteins, for example P1 and P69 (Fig. 10; Vera and Conejero 1989; Tornero et al. 1997). Consistent with the non-induction of GA upon TMV infection in tobacco is the fact that treatment of tobacco with this compound was unable to elicit PR proteins in tobacco (Van Loon 1983; Enyedi and Raskin 1993; Chen et al. 1993; Yalpani and Raskin 1993). Since GA seems to be biosynthesized from SA, one could have anticipated a role for GA as intermediary signal for inducible defenses act-
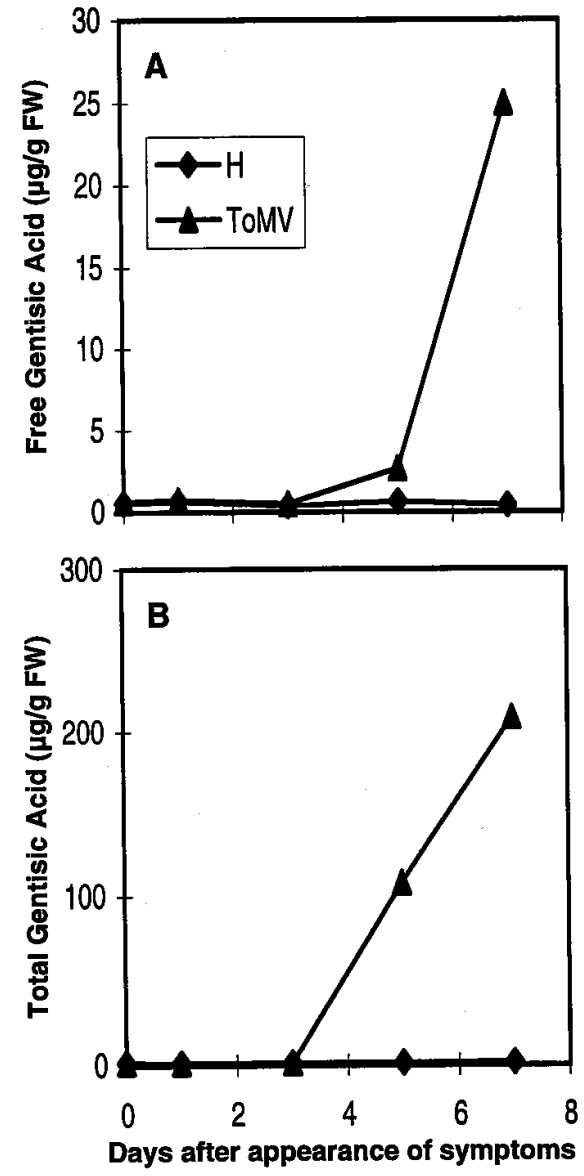

Fig. 4. Effect of tomato mosaic virus (ToMV) infection on levels of (A) free and (B) total gentisic acid in Rutgers tomato leaves. Tomato leaves were inoculated as described in Materials and Methods. Symptoms appeared 7 days later. Values are the mean of two replicates differing by less than $10 \%$. The experiment was conducted three times with similar results. $\mathrm{H}$, healthy control plants. ToMV, tomato mosaic virus-infected plants. FW, fresh weight. 
ing downstream to SA in the same signaling pathway. However, the fact that GA triggers a different subset of PR proteins than SA strongly indicates that SA and GA play complementary signaling roles in the activation of the inducible defenses of tomato. In conclusion, GA seems to have a dual defensive function: as an antimicrobial compound (Lattanzio et al. 1994) and as a component of the signaling system for activation of inducible defenses.

\section{MATERIALS AND METHODS}

\section{Plant material and treatments.}

Tomato (Lycopersicon esculentum Mill. 'Rutgers') plants were grown from seeds in a greenhouse and inoculated with CEVd 10 days after sowing (cotyledon stage) as described (Bellés et al. 1991). Symptoms of the disease appeared 10 days later. Tobacco (Nicotiana tabacum L. 'Xanthi-nc') were grown under the same conditions as tomato except that the growth temperature was $24^{\circ} \mathrm{C}$. Infection of Rutgers tomato plants with ToMV was performed with a viral extract obtained from leaves of ToMV-infected tomato plants that were ho-
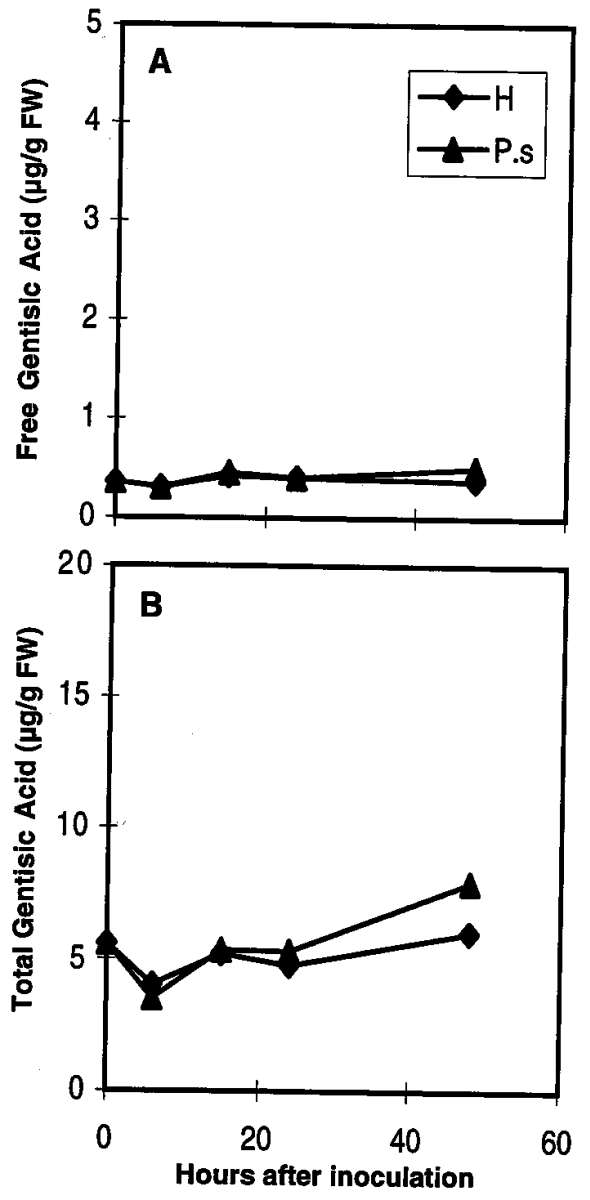

Fig. 5. Effect of Pseudomonas syringae pv. syringae infection on levels of (A) free and (B) total gentisic acid in Rutgers tomato leaves. Tomato leaves were inoculated as described in Materials and Methods. Values are the mean of two replicates differing by less than $10 \%$. The experiment was conducted three times with similar results. $\mathrm{H}$, healthy control plants. P.s., Pseudomonas syringae pv. syringae-infected plants. FW, fresh weight. mogenized in $10 \mathrm{mM}$ phosphate buffer $(\mathrm{pH} 7.2), 0.5 \%$ sodium bisulfite, $0.5 \%$ diethyldithiocarbamic acid $(1 \mathrm{~g}$ of leaf material in $20 \mathrm{ml}$ of buffer). Three-week-old tomato plants were dusted with Carborundum, and buffer (mock-inoculated control) and viral extract were applied by gently rubbing the upper face of the leaves. Symptoms appeared 7 days after infection. Infection of tomato plants with $P$. syringae pv. syringae was performed with a bacterial suspension obtained as follows: $P$. $s y$ ringae pv. syringae cultures were grown overnight at $28^{\circ} \mathrm{C}$ in 20-ml petri dishes with $\mathrm{C} 3$ agar medium (Oxoid, Basington, $\mathrm{UK}$ ) supplemented with $0.45 \mathrm{~g}$ of $\mathrm{KH}_{2} \mathrm{PO}_{4}$ per liter, $2.39 \mathrm{~g}$ of $\mathrm{Na}_{2} \mathrm{HPO}_{4} \cdot 12 \mathrm{H}_{2} \mathrm{O}(\mathrm{pH}$ 6.8) per liter. Bacterial colonies were then resuspended in sterile water to a final concentration of $\mathrm{OD}_{600}: 0.1$. Dilution plating was used to determine the final inoculum concentration, which averaged $1 \times 10^{8} \mathrm{CFU} / \mathrm{ml}$. Approximately $100 \mu \mathrm{l}$ of bacterial suspension was infiltrated into the abaxial surface with a sterile plastic syringe through three to four sites of the midribs from each leaflet. Controls were infiltrated with distilled water. In this experiment, tomato plants were infected at the 4- to 5-leaf stage. Necrotic lesions commenced to appear 24 hours after bacterial infection. To study the conversion of BA and SA to GA, 4-weekold uninoculated tomato and 8-week-old uninoculated tobacco
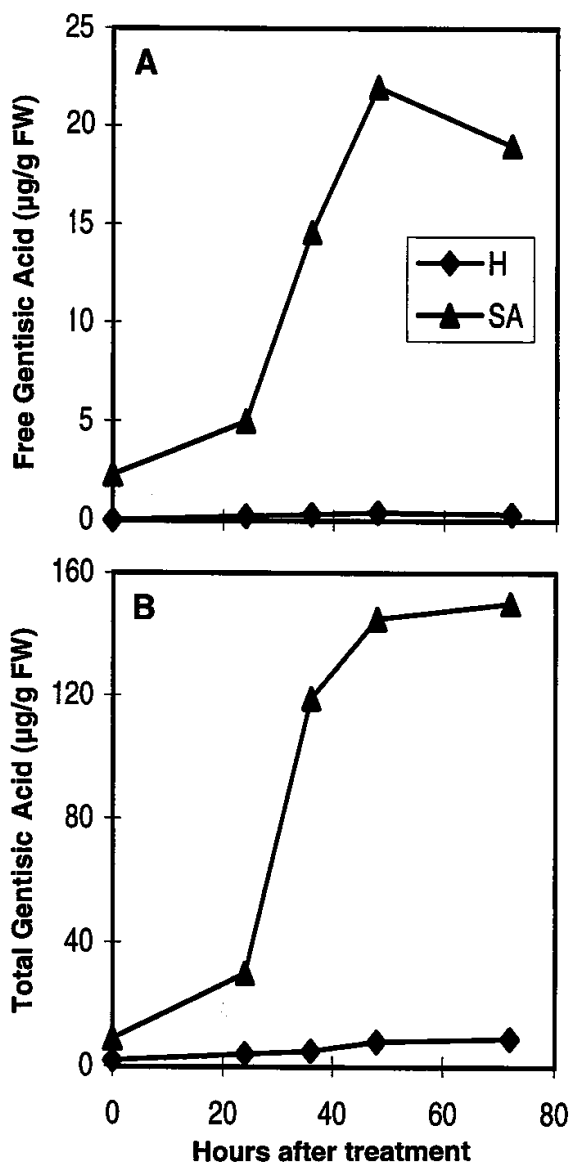

Fig. 6. Levels of (A) free and (B) total gentisic acid in Rutgers tomato leaves following spraying of the plants with $10 \mathrm{mM}$ salicylic acid. Values are the mean of two replicates differing by less than $10 \%$. The experiment was conducted three times with similar results. $H$, healthy control plants. SA, salicylic acid-treated plants. 
plants were sprayed until run-off with $10 \mathrm{mM}$ concentrations of these phenolic acids (sodium salt form). Mature expanded leaves from tomato were used to study the effect of phenolic acids on the induction of antifungal proteins in tomato. SA and GA were applied by immersing the petioles of the excised mature tomato leaves in an aqueous solution of $1 \mathrm{mM}$ phenolic acids (sodium salt form). Leaves were maintained in the same conditions as the entire plants.

\section{Extraction and quantification of phenolics.}

Extraction of free and bound phenolics from tomato and tobacco leaves $(0.25 \mathrm{~g})$ was done according to protocols previously described for SA (Raskin et al. 1989; Yalpani et al. 1991; Enyedi et al. 1992; Meuwly and Métraux 1993). Ten microliters from a total volume of the final $150 \mu \mathrm{l}$ of methanolic extract was injected into a Sentry Guard Column linked to a Symmetry $5 \mu \mathrm{m} \mathrm{C18}(4.6 \times 150 \mathrm{~mm}$; Waters, Milford, MA) column equilibrated in $85 \% 20 \mathrm{mM}$ sodium acetate buffer $(\mathrm{pH} 5)$ and $15 \%$ methanol. The temperature of the oven was $30^{\circ} \mathrm{C}$. A gradient of methanol (15 to $100 \%$ ) was applied over $10 \mathrm{~min}$. Phenolics were detected with a Water 470 fluorescence detector and quantified with a Waters 746 Data
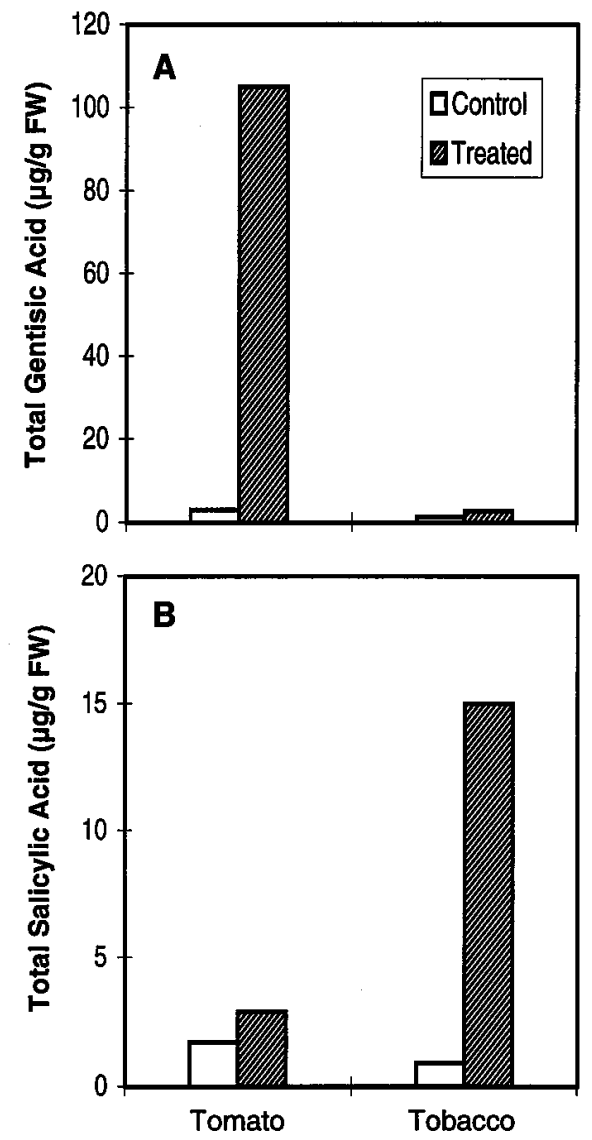

Fig. 7. A, Levels of total gentisic acid in tomato and tobacco leaves $48 \mathrm{~h}$ after plants were sprayed with $10 \mathrm{mM}$ salicylic acid. Values are the mean of two replicates differing by less than $10 \%$. The experiment was conducted three times with similar results. B, Levels of total salicylic acid in tomato and tobacco leaves $48 \mathrm{~h}$ after plants were sprayed with 10 $\mathrm{mM}$ benzoic acid. Values are the mean of two replicates differing by less than $10 \%$. The experiment was conducted three times with similar results. FW, fresh weight.
Module, using authentic standards. As in tobacco (Yalpani et al. 1993a), recovery of metabolites from tomato ranged between 30 and $50 \%$.

\section{Radiolabeling experiments.}

For radiolabeling experiments, basically the protocol described in Coquoz et al. (1998) was followed. Briefly, leaflets $(0.3 \mathrm{~g})$ from 4-week-old Rutgers tomato were transferred to an aqueous solution $(30 \mu \mathrm{l})$ containing $\left[7-{ }^{14} \mathrm{C}\right] \mathrm{SA}(30 \mathrm{nCi}, 40$ to $60 \mathrm{mCi} / \mathrm{mmol}$; Amersham, Little Chalfont, UK). After 30 min, the leaflets were kept in deionized water for 1 or $6 \mathrm{~h}$. Then, phenolics were extracted in $1 \mathrm{ml}$ of $100 \%$ methanol and centrifuged at $10,000 \times g$ for $10 \mathrm{~min}$ at room temperature. The supernatant $(1 \mathrm{ml})$ was dried under nitrogen at room temperature to a final volume of $100 \mu$ l. Twenty microliters was analyzed by HPLC as described above. Radioactive phenolic compounds were monitored with an on-line radioactivity detector LB 509 (EGG Berthold, Bad Wildbad-Germany), with OptiFlow safe 1 as liquid scintillation cocktail $(3 \mathrm{ml} / \mathrm{min}$ ) (EGG Berthold).

\section{Identification of GA.}

To identify the unknown peak in the HPLC elution profile from the methanolic extracts, $10 \mathrm{~g}$ of CEVd-infected leaves,
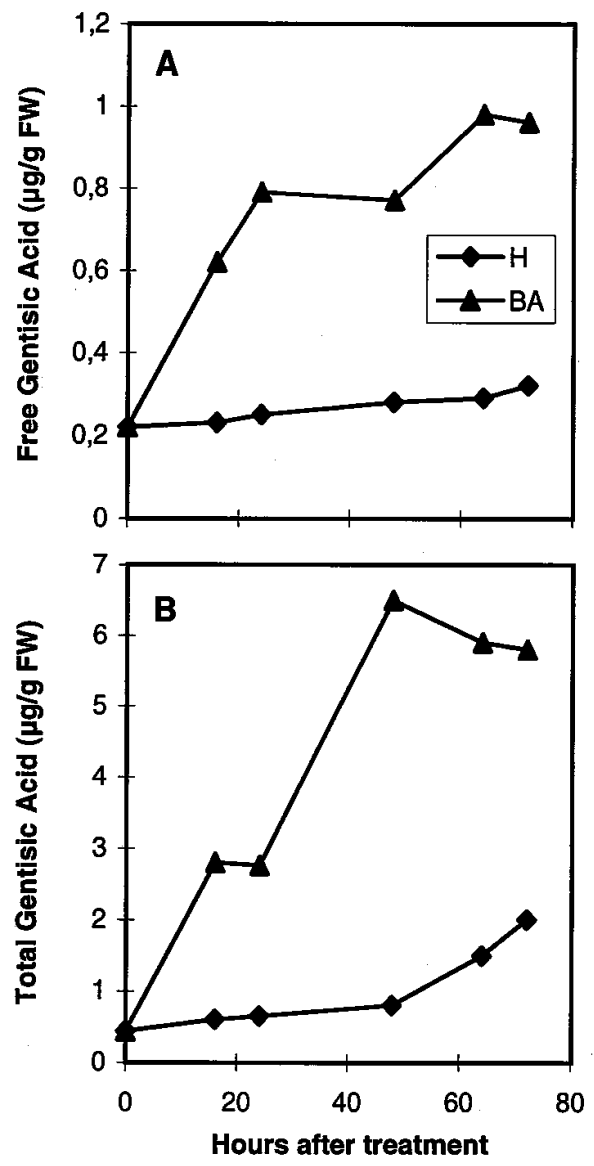

Fig. 8. Levels of (A) free and (B) total gentisic acid in Rutgers tomato leaves after plants were sprayed with $10 \mathrm{mM}$ benzoic acid. Values are the mean of two replicates differing by less than $10 \%$. The experiment was conducted three times with similar results. $\mathrm{H}$, healthy control plants. BA, benzoic acid-treated plants. 
showing strong symptoms of the disease, was extracted according to previous descriptions (Enyedi et al. 1992). One hundred microliters was injected onto a Prep Nova-Pak HR 6 $\mu \mathrm{m}$ C18 column $(7.8 \times 300 \mathrm{~mm}$, Waters $)$. The peak corresponding to the unknown compound was collected from various injections and dried under nitrogen at room temperature. The HPLC-purified unknown peak was re-extracted with ethylacetate (Yalpani et al. 1993b). Then, sodium acetate was eliminated by centrifugation at $10,000 \times g$ for $20 \mathrm{~min}$. The
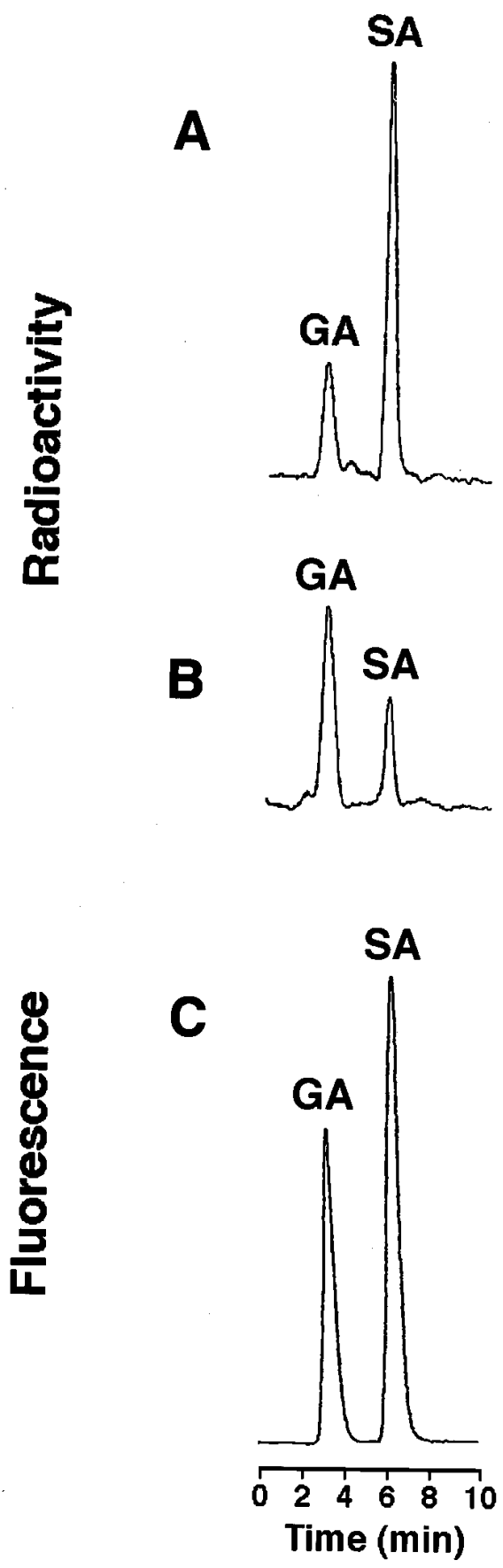

Fig. 9. High-performance liquid chromatography chromatograms showing incorporation of radioactivity from $\left[7-{ }^{14} \mathrm{C}\right]$ salicylic acid (SA) into gentisic acid (GA) in tomato leaflets (A) $1 \mathrm{~h}$ and (B) $6 \mathrm{~h}$ after treatment, as well as (C) SA and GA authentic standards. supernatant was dried under nitrogen at room temperature. The recovered amount of unknown compound was about 5 $\mathrm{mg}$. The structure of this compound was determined by means of ${ }^{1} \mathrm{HMNR}$ spectroscopy (Varian Gemini $300 \mathrm{MHz}$ ) and mass spectrometry (HPLC-MS; Waters Integrity System).

\section{Antifungal protein analysis.}

Mature leaves were homogenized at $4^{\circ} \mathrm{C}$ in a McIlvaine's buffer ( $\mathrm{pH} 2.8$ ) containing $30 \mathrm{mM}$ 2-mercaptoethanol (1 ml of buffer per $\mathrm{g}$ of fresh weight). The homogenate was filtered through cheesecloth and centrifuged at $20,000 \times g$ for $20 \mathrm{~min}$ at $4^{\circ} \mathrm{C}$. Protein content was measured by the method of Bradford (1976) with bovine serum albumin as a standard. Ten micrograms of protein was loaded per lane for sodium dodecyl sulfate-polyacrylamide gel electrophoresis (SDS-PAGE) according to the procedure previously described (Granell et al. 1987). Proteins were electroblotted to Optitran membranes (Schleicher and Schuell, Dassel, Germany) with a Trans-Blot Cell (Bio-Rad, Hercules, CA) as previously described (Bellés et al. 1992). We have used antisera raised against purified antifungal PR proteins P32 and P34 (García-Breijo et al. 1990) at a dilution of 1:1,000 (antibody against PR-32 cross-reacted with PR-P34), P23 (Rodrigo et al. 1993) at 1:300, and P1 (Vera et al. 1988) at 1:1,000. The secondary antiserum (Promega, Madison, WI) was used at a dilution of 1:7,500.

\section{ACKNOWLEDGMENTS}

We want to thank the reviewers for their detailed comments. We thank Pablo Vera and Concha Jordá for gifts of ToMV inoculum and $P$. syringae pv. syringae cultures, respectively, and Ismael Rodrigo for his assistance with Figure 10. This work has been supported by grants from Dirección General de Investigación Científica y Técnica (PB96-1057), Consellería de Agricultura, Pesca y Alimentación (GV-CAPA 97-09C1), as well as by contract IC18-CT96-0124 from the European Union.

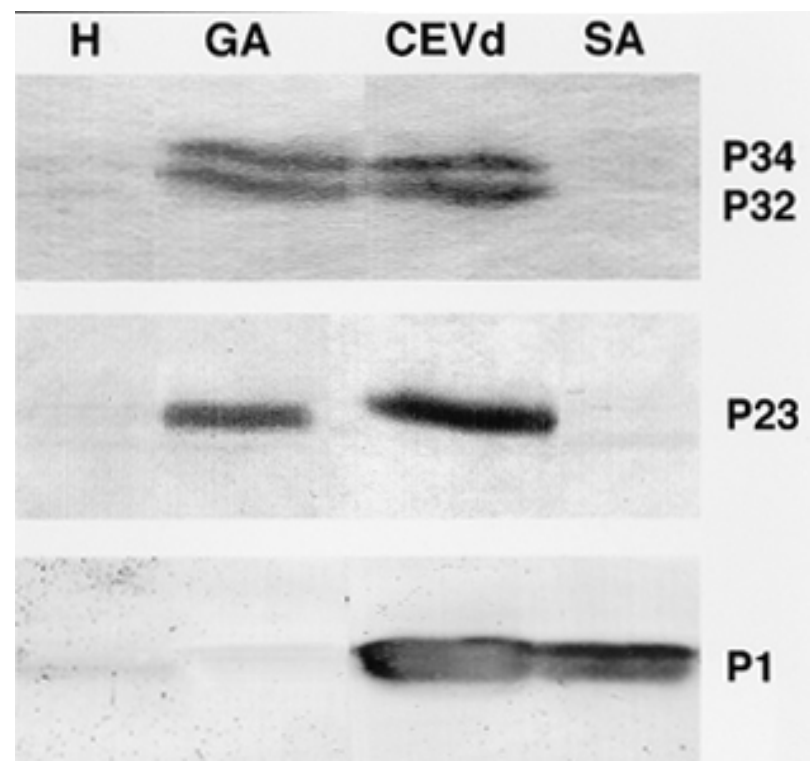

Fig. 10. Immunoblots of crude tomato leaf extracts treated with gentisic or salicylic $(1 \mathrm{mM})$ acids or infected with the citrus exocortis viroid $(\mathrm{CEVd})$, reacted with the antiserum of the antifungal pathogenesisrelated (PR) proteins $\mathrm{P} 32$ and $\mathrm{P} 34$, protein $\mathrm{P} 23$, and protein $\mathrm{P} 1$. Extracts were carried out at $\mathrm{pH} 2.8,72 \mathrm{~h}$ after the treatments, or 5 days after appearance of symptoms in CEVd-infected tomato leaves. 


\section{LITERATURE CITED}

Baker, B., Zambryski, P., Staskawicz, B., and Dinesh-Kumar, S. P. 1997. Signaling in plant-microbe interactions. Science 276:721-733.

Bellés, J. M., Carbonell, J., and Conejero, V. 1991. Polyamines in plants infected by citrus exocortis viroid or treated with silver ions and ethephon. Plant Physiol. 96:1053-1059.

Bellés, J. M., Tornero, P., and Conejero, V. 1992. Pathogenesis-related proteins and polyamines in a developmental mutant of tomato, Epinastic. Plant Physiol. 98:1502-1505.

Bent, A. R. 1996. Plant disease resistance gene: Function meets structure. Plant Cell 8:757-1771.

Bradford, M. M. 1976. A rapid and sensitive method for the quantitation of microgram quantities of protein utilizing the principle of proteindye binding. Anal Biochem. 72:248-254.

Cao, H., Glazebrook, J., Clarke, J. D., Volko, S., and Dong, X. 1997. The Arabidopsis NPR1 gene that controls systemic acquired resistance encodes a novel protein containing ankyrin repeats. Cell 88:5763.

Chadha, K. C., and Brown, S. A. 1974. Biosynthesis of phenolic acids in tomato plants infected with Agrobacterium tumefaciens. Can. J. Bot. 52:2041-2047.

Chen, Z., Silva, H., and Klessig, D. F. 1993. Active oxygen species in the induction of plant systemic acquired resistance by salicylic acid. Science 262:1883-1886.

Conejero, V., Bellés, J. M., García-Breijo, F., Garro, R., HernándezYago, J., Rodrigo, I., and Vera, P. 1990. Signalling in viroid pathogenesis. Pages 233-261 in: Recognition and Response in Plant-Virus Interactions. Springer-Verlag, Berlin.

Coquoz, J. L., Buchala, A., and Métraux, J. P. 1998. The biosynthesis of salicylic acid in potato plants. Plant Physiol. 117:1095-1101.

Delaney, T. P., Uknes, S., Vernooij, B., Friedrich, L., Weymann, K., Negrotto, D., Gaffney, T., Gut-Rella, M., Kessmann, H., Ward, E., and Ryals, J. 1994. A central role of salicylic acid in disease resistance. Science 266:1247-1250.

Dempsey, D. A., Pathirana, M. S., Wobbe, K. K., and Klessig, D. F. 1997. Identification of an Arabidopsis locus required for resistance to turnip crinkle virus. Plant J. 11:301-311.

Dixon, R. A., Harrison, J. J., and Lamb, C. J. 1994. Early events in the activation of plant defense responses. Annu. Rev. Phytopathol. 32: 479-501.

Durner, J., Shah, J., and Klessig, D. F. 1997. Salicylic acid and disease resistance in plants. Trends Plant Sci. 2:266-274.

Enyedi, A. J., and Raskin, I. 1993. Induction of UDP-glucose: Salicylic acid glucosyltransferase activity in tobacco mosaic virus-inoculated tobacco (Nicotiana tabacum). Plant Physiol. 101:1375-1380.

Enyedi, A. J., Yalpani, N., Silverman, P., and Raskin, I. 1992. Localization, conjugation and function of salicylic acid in tobacco during the hypersensitive reaction to tobacco mosaic virus. Proc. Natl. Acad. Sci. USA 89:2480-2484.

Gaffney, T., Friedrich, L., Vernooij, B., Negretto, D., Nye, G., Uknes, S., Ward, E., Kessmann, H., and Ryals, J. 1993. Requirement of salicylic acid for the induction of systemic acquired resistance. Science 261: 754-756

García-Breijo, F. J., Garro, R., and Conejero, V. 1990. C 7 (P32) and $\mathrm{C}_{6}(\mathrm{P} 34) \mathrm{PR}$ proteins induced in tomato leaves by citrus exocortis viroid infection are chitinases. Physiol. Mol. Plant Pathol. 36:249-260.

Granell, A., Bellés, J. M., and Conejero, V. 1987. Induction of pathogenesis-related proteins in tomato by citrus exocortis viroid, silver and ethephon. Physiol. Mol. Plant Pathol. 31:83-90.

Griffiths, L. A. 1959. On the distribution of gentisic acid in green plants. J. Exp. Bot. 10:437-442.

Hunt, M. D., Delaney, T. P., Dietrich, R. A., Weymann, K. B., Dangl, J. L., and Ryals, J. A. 1997. Salicylate-independent lesion formation in Arabidopsis $l s d$ mutants. Mol. Plant-Microbe Interact. 10:531-536.

Ibrahim, R. K., and Towers G. H. N. 1959. Conversion of salicylic acid to gentisic acid and o-pyrocatechuic acid, all labelled with carbon-14, in plants. Nature 184:1803.

Kombrink, E., and Somssich, Y. E. 1995. Defense responses of plants to pathogens. Adv. Bot. Res. 21:1-34.

Lattanzio, V., De Cicco, D., Di Venere, D., Lima, G., and Salerno, M. 1994. Antifungal activity of phenolics against fungi commonly encountered during storage. Ital. J. Food Sci. 6:23-30.

Lee, H., and Raskin, I. 1998. Glucosylation of salicylic acid in Nico- tiana tabacum Cv. Xanthi-nc. Phytopathology 88:692-697.

León, J., Shulaev, V., Yalpani, N., Lawton, M. A., and Raskin, I. 1995. Benzoic acid 2-hydroxylase, a soluble oxygenase from tobacco, catalyzes salicylic acid biosynthesis. Proc. Natl. Acad. Sci. USA 92: 10413-10417.

León, J., Yalpani, N, Raskin, I., and Lawton, M. A. 1993. Induction of benzoic acid 2-hydroxylase in virus-inoculated tobacco. Plant Physiol. 103:323-328.

Maher, E. A., Bate, N. J., Ni, W., Elkind, Y., Dixon, R. A., and Lamb, C. J. 1994. Increased disease susceptibility of transgenic tobacco plants with suppressed levels of preformed phenylpropanoid products. Proc. Natl. Acad. Sci. USA 91:7802-7806.

Malamy, J., Carr, J. P., Klessig, D. F., and Radkin, I. 1990. Salicylic acid: A likely endogenous signal in the resistance response of tobacco to viral infection. Science 250:1002-1004.

Malamy, J., Hening, J., and Klessig, D. F. 1992. Temperature-dependent induction of salicylic acid and its conjugates during the resistance response to tobacco mosaic virus infection. Plant Cell 4:359-366.

Malamy, J., Sánchez-Casas, P., Hennig, J., Guo, A., and Klessig, D. F. 1996. Dissection of the salicylic acid signaling pathway in tobacco. Mol. Plant-Microbe Interact. 9:474-482.

Métraux, J. P., and Raskin, I. 1993. Role of phenolics in plant disease resistance. Pages 191-209 in: Biotechnology in Plant Disease Control. Wiley-Liss, New York.

Métraux, J. P., Signer, H. J., Ryals, J., Ward, E., Wyss-Benz, M., Gaudin, J., Raschdorf, K., Schmid, E., Blum, W., and Inverardi, B. 1990. Increase in salicylic acid at the onset of systemic acquired resistance in cucumber. Science 250:1004-1006.

Meuwly, P., and Métraux, J. P. 1993. Ortho-anisic acid as internal standard for the simultaneous quantification of salicylic acid and its putative biosynthetic precursors in cucumber leaves. Anal. Biochem. 214:500-505.

Meuwly, P., Mölders, W., Buchala, A., and Métraux, J. P. 1995. Local and systemic biosynthesis of salicylic acid in infected cucumber plants. Plant Physiol. 109:1107-1114.

Penninckx, I. A. M. A., Eggermont, K., Terras, F. R. G., Thomma, B. P. H. J., Samblanx, G. W., Buchala, A., Métraux, J. P., Manners, J. M., and Broekaert, W. F. 1996. Pathogen-induced systemic activation of a plant defensin gene in Arabidopsis follows a salicylic acidindependent pathway. Plant Cell 8:2309-2323.

Raskin, I., Turner, I. M., and Melander, W. R. 1989. Regulation of heat production in the inflorescences of an Arum lily by endogenous salicylic acid. Proc. Natl. Acad. Sci. USA 86:2214-2218.

Rasmussen, J. B., Hammerschmidt, R., and Zook, M. N. 1991. Systemic induction of salicylic acid accumulation in cucumber after inoculation with Pseudomonas syringae pv. syringae. Plant Physiol. 97:13421347.

Rodrigo, I., Vera, P., Tornero, P., Hernández-Yago, J., and Conejero, V. 1993. cDNA cloning of viroid-induced tomato pathogenesis-related protein P23. Characterization as a vacuolar antifungal factor. Plant Physiol. 102:939-945.

Ryals, J. A., Neuenschwander, U. H., Willits, M. G., Molina, A., Steiner, H.-Y., and Hunt, M. D. 1996. Systemic acquired resistance. Plant Cell 8:1809-1819.

Ryals, J., Weymann, K., Lawton, K., Friedrich, L., Ellis, D., Steiner, H.Y., Johnson, J., Delaney, T. P., Jesse, T., Vos, P., and Uknes, S. 1997. The Arabidopsis NIM1 protein shows homology to the mammalian transcription factor inhibitor IkB. Plant Cell 9:425-439.

Schulz, M., Schnabl, H., Manthe, B., Schweihofen, B., and Casser, I. 1993. Uptake and detoxification of salicylic acid by Vicia faba and Fagopyrum esculentum. Phytochemistry 33:291-294.

Shirasu, K., Nakajima, H., Rajasekhar, V. K., Dixon, R. A., and Lamb, C. 1997. Salicylic acid potentiates an agonist-dependent gain control that amplifies pathogen signal in the activation of defense mechanisms. Plant Cell 9:261-270.

Silverman, P., Nuckles, E., Ye, X. S., Kuc, J., and Raskin, I. 1993. Salicylic acid, ethylene, and pathogen resistance in tobacco Mol. PlantMicrobe Interact. 6:775-781.

Sticher, L., Mauch-Mani, B., and Métraux, J. P. 1997. Systemic acquired resistance. Annu. Rev. Phytopathol. 35:235-270.

Tornero, P., Gadea, J., Conejero, V., and Vera, P. 1997. Two PR1 genes from tomato are differentially regulated and reveal a novel mode of expression for a pathogenesis-related gene during the hypersensitive response and development. Mol. Plant-Microbe Interact. 10:624-634. 
Uknes, S., Mauch-Mani, B., Moyer, M., Potter, S., Williams, S., Dincher, S., Chandler, D. Slusarenko, A., Ward, E., and Ryals, J. 1992. Acquired resistance in Arabidopsis. Plant Cell 4:645-656.

Uknes, S., Winter, A. M., Delaney, T., Vernooij, B., Morse, A., Friedrich, L., Nye, G., Potter, S., Ward, E., and Ryals, J. 1993. Biological induction of systemic acquired resistance in Arabidopsis. Mol. PlantMicrobe Interact. 6:692-698.

Vallélian-Bindschedler, L., Métraux, J.-P., and Schweizer, P. 1998. Salicylic acid accumulation in barley is pathogen specific but not required for defense-gene activation. Mol. Plant-Microbe Interact. 7:702-705.

Van Kan, J. A. L., Cozijnsen, T., Danhash, N., and de Wit, P. J. G. M. 1995 Induction of tomato stress protein mRNAs by ethephon, 2,6dichloroisonicotinic acid and salicylate. Plant Mol. Biol. 27:1205-1213.

Van Loon, L. C. 1983. The induction of pathogenesis-related proteins by pathogens and specific chemicals. Neth. J. Plant Pathol. 89:265-273.

Vera, P., and Conejero, V. 1989. The induction and accumulation of the pathogenesis-related P69 proteinase in tomato during citrus exocortis viroid infection and in response to chemical treatments. Physiol. Mol. Plant Pathol. 34:323-334.

Vera, P., Hernández Yago, J., and Conejero, V. 1988. Immunocytochemical localization of the major pathogenesis-related (PR) protein of tomato plants. Plant Science 55:223-230

Vidal, S., Eriksson, A. R. B., Montesano, M., Denecke, J., and Palva, E. T. 1998. Cell wall-degrading enzymes from Erwinia carotovora co- operate in the salicylic acid-independent induction of a plant defense response. Mol. Plant-Microbe Interact. 11:23-32.

Ward, E. R., Uknes, S. J., Williams, S. C., Dincher, S. S., Wiederhold, D. L., Alexander, D. C., Ahl-Goy, P., Métraux, J.-P., and Ryals, J. 1991. Coordinate gene activity in response to agents that induce systemic acquired resistance. Plant Cell 3:1085-1094.

Yalpani, N., León, J., Lawton, M. A., and Raskin, I. 1993a. Pathway of salicylic acid biosynthesis in healthy and virus-inoculated tobacco. Plant Physiol. 103:315-321

Yalpani, N., and Raskin, I. 1993. Salicylic acid: A systemic signal in induced plant disease resistance. Trends Microbiol. 1:88-92

Yalpani, N., Shulaev, V., and Raskin, I. 1993b. Endogenous salicylic acid levels correlate with accumulation of pathogenesis-related proteins and virus resistance in tobacco. Phytopathology 83:702-708.

Yalpani, N., Silverman, P., Wilson, T. M. A., Kleier, D. A., and Raskin, I. 1991. Salicylic acid is a systemic signal and an inducer of pathogenesis-related proteins in virus-infected tobacco. Plant Cell 3:809818.

Yang, Y., Shah, J., and Klessig, D. F. 1997. Signal perception and transduction in plant defense responses. Genes Dev. 11:1621-1639.

Zhang, S. Q., and Klessig, D. F. 1998. Resistance gene N-mediated de novo synthesis and activation of a tobacco mitogen-activated protein kinase by tobacco mosaic virus infection. Proc. Natl. Acad. Sci. USA 95:7433-7438. 